\title{
THE EMIGRATION POTENTIAL OF ROMANIA
}

\author{
Endre Sik \\ Social Science Information Center, Budapest, Hungary
}

\section{The Soclal Characterlstles of Potential Emigrants from Romanla}

Last fall I had the opportunity to spend one week in Bucharest and meet Romanian researchers studying migration. From them I learned that since the revolution in December 1989 more than 4 million passports had been issued and for the first time in decades citizens are allowed to keep their passports at home and travel whenever they want. For obvious reasons, most Romanians are enthusiastic about travelling abroad. The question remains, however, whether particular groups or strata are especially keen to emigrate.

A recent survey carried out under the auspices of the Erasmus Foundation helps shed light on that issue. The fieldwork was done in 1991 on a stratified representative sample of 1,264 respondents. Two of the survey questions may be considered indicators of emigration potential:

(1.) If you had a chance to choose which country you want to live in, would you choose [name of country]?

1 - definitely

2 - probably yes

3 - probably not

4 - by no means / absolutely not

(2.) Do you think that if you had lived in a western country

1 -you would have got on better?

2 - it would have been the same?

3 - it would have been worse?

The responses to the first question indicate that every tenth Romanian thinks about emigration in positive terms, while two out of ten are uncertain. The remainder do not want to emigrate. The responses to the second question show that every second Romanian expects that he or she would have had a better life in the West.
While those who are ready to emigrate are very likely to believe they would have a better life in the West, among those who do not want to emigrate there are many who also assume that living in the West would offer them a better life. Specifically, 10 percent of Romanians are potential emigrants in the sense that they are ready to move to the West and feel they would have a better life there. Another 10 percent of Romanians are ambivalent potential emigrants, unsure whether they want to emigrate but certain they would have a better life in the West. An additional 31 percent of Romanians do not want to emigrate even though they know they would have a better life in the West. We may refer to this third group as reluctant dreamers. Finally, 49 percent of Romanians are confirmed non-emigrants who neither want to leave Romania nor believe their lives would be better elsewhere.

The potential emigrants are mainly male urban dewellers who are young and relatively well educated. The sharpest differences between potential emigrants and the total sample are in terms of age and urbanism. While 27 percent of the sample are under 30 years of age and 55 percent are of urban origin, the respective figures among potential migrants are 43 percent and 70 percent.

Table 1 shows the relationship between social status and mobility, on the one hand, and each of the four groups identified above, on the other.

Table 1 Group Type and Social Status/Mobility ( $\mathrm{n}=911$; percent in brackets)

Social Status/Mobility Type

1. Stable upper 2. Upwardly mobile upper

3. Stable Middle 4. Upwardly mobile middle

5. Stable working 6. Downwardly mobile

$\begin{array}{lrrrrrr}\text { Group Type } & \mathbf{1} & \mathbf{2} & \mathbf{3} & \mathbf{4} & \mathbf{5} & \mathbf{6} \\ \text { Potential emigrants } & 15 & 26 & 35 & 12 & 5 & 13\end{array}$

(15) (18) (9) (11) (6) (14)

Ambivalent

Potential emigrants

$7 \quad 18$

39

96

(10)

(8)

Reluctant dreamers

49

136

38

17

Non-emigrants

31

Total

(chi-square $=37.169$, d.f. $=15, p=.0012$ )

The author is grateful to the Erasmus Foundation for permission to analyze data from their survey. This preliminary analysis is part of a larger work written for a project on Austrian and Hungarian refugee policies organized by the Interdisciplinary Centre for Comparative Research in the Social Sciences, Vienna. 
Comparing the percentages across the top row, we see that the groups with the greatest emigration potential are the upwardly mobile upper class and the stable upper class. The groups with the least emigration potential are the stable working class, the stable middle class and the upwardly mobile middle class. The downwardly mobile of all classes occupy an intermediate position, although they are closer to the groups with greater emigration potental. We may conclude that emigration potential is associated with upper class position and, to a lesser degree, downward mobility in all classes.

Table 2 sets out the relationship between group type and religion. Our sample is divided into two groups those who are of Eastern Orthodox background and those who are not. Again inspecting the percentages across the first row, it clearly shows that non-Orthodox people are the most likely to want to emigrate. Since the non-Orthodox are likely to be of nonRomanian ethnic background Hungarians, Jews, etc. - we may infer that social marginality is associated with high emigration potential in Romania.

In sum, my major conclusions about the sociodemographic determinants of emigration potential are:

- If the 10 percent of the Romanian population which in 1991 seemed ready to emigrate would actually do so, then Romania would lose many of its most mobile and resourceful people.

- The sociodemographic ideal type of the potential Romanian migrant is young, male, urbanized, highlyeducated and upper-class.

- It also seems that ethnic and religious minority status increase the likelihood of wanting to emigrate.

- Results of the survey, too complex to present in the space available here, show, paradoxically, that people with close community ties are the least inclined to want to emigrate. This may be interpreted in two opposing ways. First, it may be that appropriate incentives could mitigate the desire of potential emigrants to leave. On the other hand, this finding might also signify the potential for chain migration: close ties may serve as the social mechanism encouraging early emigrants to later draw their Romanians friends and relatives to new homelands.

\section{Negative Soclo-Political Attltudes and Romanlan Emlgration}

A part from sociodemographic factors, attitudes can also influence emigration potential: political values, level of satisfaction and of fear, trust in the state, etc. We shall see that the more negative one's attitudes towards Romanian society, the stronger one's desire to emigrate.

Let us begin with respondents' attitudes toward the economic situation. There is hardly any difference among generations in desire to emigrate. Slightly more than half the population feels that their economic circumstances are worse than their parents' situation was at the same age. Non-emigrants are somewhat more dour than the average, which shows that most people believe

Table 2 Group Type by Religion ( $n=1,131$; percent in brackets)

\section{Non-orthodox Orthodox}

$\begin{array}{lrcc}\text { Potential emigrants } & 30 & (21) & 88 \\ \text { Ambivalent } & & & \\ \quad \text { potential emigrants } & 30 & (21) & 77 \\ \text { Reluctant dreamers } & 34 & (24) & 315 \\ \text { Non-emigrants } & 47 & (33) & 510 \\ \text { Total } & 141 & (100) & 990 \\ \text { (chi-square }=52.584, \text { d.f. }=3, \mathrm{p}=.0000)\end{array}$

that emigration is not the way to halt economic deterioration.

Whether they are asked about the recent past, the present or the future, potential emigrants are much more critical than others of various facets of Romanian society. The sharpest difference emerges when people are asked to consider the future. For example, when their negative attitudes towards the future of work and the economy were measured, potential emigrants scored 178 percent higher than ambivalent potential emigrants,

Table 3: Attitudes by Group Type

\section{Economic Change Too Slow}

(in percent; $n=1,048$ )

\section{Politically Satisfied}

(10-point scale; $n=1,078$ )

\begin{tabular}{lcc} 
& I. & II. \\
Potential emigrants & 72 & 3.6 \\
Ambivalent & & \\
$\quad$ potential emigrants & 71 & 3.7 \\
Reluctant dreamers & 56 & 5.4 \\
Non-emigrants & 37 & 7.1 \\
Average & 50 & 5.9 \\
\hline
\end{tabular}

242 percent higher than reluctant dreamers and fully 426 percent higher than non-emigrants. Similarly, when Romanians are asked about the pace of change in the economy, potential emigrants were much more likely to view the pace of change as "too slow" (see Table 3-I). In the light of these findings it is not surprising that potential emigrants also registered lowest on a scale of satisfaction with the Romanian government (see Table 3-II). Where 10 indicates total satisfaction and 1 indicates total dissatisfaction, non-emigrants scored 7.1 and potential emigrants 3.6. These findings round out our profile of the ideal-type Romanian emigrant, who, in addition to possessing the sociodemogrpahic characteristics outlined above, is the most deeply dissatisfied member of a deeply dissatisfied citizenry. 圆 